\title{
Investigating Aspects of the Capital Budgeting Process Used in the Evaluation of Investment Projects
}

\section{J H Hall}

Department of Accounting \& Finance, University of Pretoria

\section{ABSTRACT}

Given the importance of capital investment, not only for the country as a whole but the creation of shareholder wealth by individual firms, it is vital to investigate the practices used to evaluate these projects. The findings of this study suggest that the most important stages in the capital budgeting process are project definition and cash flow estimation, not financial analysis. Further, in the evaluation of capital investment projects, South African companies seem to prefer Return on Investment and Internal Rate of Return as methods to determine the feasibility of a project. The use of these methods is influenced by the size of a company's annual capital budget, as there is a correlation between a company's annual capital budget and a preference for these methods.

JEL M 20

\section{INTRODUCTION}

During recent years many opportunities arose for local companies because international trade restrictions have been lifted. There was suddenly an opportunity to do business in the global market. This resulted in vast expansions of capital investment projects as many companies increased their production capacities at home and abroad. These investments took the form of production equipment purchases, investments in and an expansion of production facilities and larger investments such as acquisitions and even mergers.

From 1991 to 1994 South Africa's gross domestic fixed investment remained constant in real terms. However, during the period 1994 to 1998 there was an increase of $7.20 \%$ per year in real values (QB, March 1999).

There are several methods to evaluate capital investment decisions. Given the importance of capital investment, not only for the country as a whole, but also for the creation of shareholder wealth for individual firms, it may be helpful to 
investigate the practices used to evaluate these projects. The findings are compared with the theoretical principles and with the results of similar studies.

\section{RESEARCH OBJECTIVES}

The joint objective of this study is to give a brief overview of the capital budgeting process. First, an overview of the literature is sketched. Then, an empirical study investigates a number of aspects of the capital budgeting process as practised by South African companies in the evaluation of capital investment projects.

\section{HYPOTHESES}

Although the hypotheses tested in this study are statistical rather than deterministic in nature, they are stated below as if they were deterministic simply to keep the terminology as close as possible to everyday language.

The hypotheses tested in this study are the following :

\section{Hypothesis I}

The most important stage in the capital budgeting process is financial analysis and project selection.

\section{Hypothesis 2}

Cash flow forecasting methods are based on quantitative methods.

\section{Hypothesis 3}

The most popular capital investment techniques applied by decision-makers are based on percentages which they derive from the Internal Rate of Return and Return on Investment.

\section{Hypothesis 4}

The capital budgeting method used should not be influenced by the size of the annual capital budget.

Hypothesis 5

Capital investment decisions are mostly accepted on financial criteria. 


\section{THE CAPITAL INVESTMENT DECISION}

This section provides a brief overview of aspects of the capital budgeting process.

In its simplest form, an investment decision can be described as a firm's decision to make a cash outlay in order to receive, in return, future cash inflows (Lumby, 1991: 23). Du Toit, Neuland and Oost (1997: 2) define capital budgeting as the identification, evaluation and selection of the long-term or fixed assets that will increase shareholder value.

Tomorrow's business success depends on investment decisions made today. Procedures or aspects of the investment decision that are used to help management make investment decisions are often inadequate and misleading. Business organisations are continually faced with the problem of deciding whether the commitment of resources - time or money - is worthwhile in terms of the expected benefits. If the expected benefits are likely to accrue over a relatively long time, the solution is more complex and chances of making an incorrect decision increase (Biernan \& Smidt, 1993: 4).

The capital budgeting process can be divided into four stages, namely:

- identification and development of investment proposals;

o financial evaluation of projects;

- implementation of projects; and

- project review.

Various aspects of this process are investigated in the empirical study.

A number of techniques are used to evaluate investment opportunities. The most important techniques are Internal Rate of Return (IRR), Present Value Payback (PVP), Accounting Rate of Retum (ARR), the Profitability Index (PI) and Net Present Value (NPV). It falls beyond the scope of this study to explain or elaborate further on these techniques.

As a capital budgeting criterion, the IRR is the most popular criterion because people are taught since childhood that measurements should be conducted in terms of a percentage rate. It may be argued, however that the IRR is not a good criterion due to its inferiority with regard to poor reinvestment rate assumptions, the fact that it violates the value added principle, and that more than one IRR can result for the same project. 
The empirical study is conducted in order to address the various hypotheses set out above. The method used to conduct the empirical study and the research results are discussed below.

\section{RESEARCH METHOD}

\section{Description of the population}

The population chosen was companies listed on the Industrial Sector of the Johannesburg Stock Exchange.

Industrial companies were selected for the research due to the fact that the capital investment decision features more prominently in these companies because it relates closely to production capacities.

\section{Source of data}

The information used in this study was obtained in collaboration with the Bureau of Financial Analysis at the Graduate School of Management at the University of Pretoria. A questionnaire was sent to the selected sample.

\section{Sample selection}

At the time of the study (1998), there were 358 companies in the Industrial Sector listed on the Johannesburg Stock Exchange. Owing to financial and time constraints, these companies were listed alphabetically and only the first 300 were selected as a sample.

\section{Questionnaires}

The questionnaire consisted of 24 questions divided into three sections:

The first section focussed on the company and decision-maker profile, which is necessary to categorise the data of the various responses. It gives an indication as to the seniority of the decision-maker and his/her background. It also indicates the amount budgeted to be invested in capital projects as well as the extent of the company's operations. Nine questions were asked in Section One of the questionnaire.

Section Two of the questionnaire examined the capital budgeting techniques used in the capital investment process with a specific focus on the techniques that are most often used to assess the viability of different operations. This section consisted of ten questions. 
The last section deals with the incorporation of risk into the capital budgeting decision and is discussed in a subsequent article,

\section{Data collection and analysis}

As stated above, a list of all companies in the Industrial Sector of the Johannesburg Stock Exchange with addresses was made available by the Bureau of Financial Analysis at the Graduate School of Management at the University of Pretoria. Questionnaires were sent to 300 companies, during the second half of 1998.

Responses were encoded with the assistance of the Graduate School of Management. The data was computerised using a computer software package called SAS (Statistical Analysis System). A spreadsheet reflecting the respondents' answers was compiled and encoded for use as input to the SASprogramme.

\section{EMPIRICAL RESULTS}

\section{Introduction}

When the data from the questionnaires was analysed, it was found that, although the majority of questions have only one logical answer, the respondents in some instance selected more than one answer. In order to apply a consistent approach in capturing the data, the first answer given to a specific question was regarded as the respondent's answer for capturing purposes.

\section{General observations on the data}

The total response from the population of 300 amounted to 70 questionnaires $(23.33 \%)$, which were categorised as 'usable' and 'non-usable'. The 'usable' responses amounted to 65 questionnaires, giving a response rate of $21.67 \%$.

When the data were analysed, it was found that the questionnaires had been completed mainly by the financial directors of the various companies $(55.4 \%)$. Forms completed by financial managers amounted to $29.2 \%$, while the remaining $15.4 \%$ were completed either by the chief executive officer $(7.7 \%)$, the company secretary $(2.5 \%)$, the treasurer $(1.5 \%)$ or other senior management $(3.7 \%)$.

The respondents generally have a high level of experience within their respective companies, as $60 \%$ of them have been with their companies for more 
than five years. Of the remaining $40 \%$, only $24,6 \%$ have been with the company for less than two years. They are highly skilled people (all respondents have a tertiary qualification) and $61.5 \%$ have a postgraduate qualification (Honours or Masters).

The majority of the respondents $(13.8 \%)$ are in the Stores sector while $12.3 \%$ indicated that they are in the Industrial Holdings sector, and a further $12.3 \%$ are in the Food sector.

Table 1 and Table 2 illustrate the respondents' total assets, the amount of annual sales and the size of the annual capital budget. The analysis shows that the respondents fall in two main categories, namely, $35.4 \%$ with assets between $\mathrm{R} 100$ million and R500 million and $32.3 \%$ with assets of more than R1 billion.

\section{Table 1 The amount of total assets}

\begin{tabular}{|l|r|}
\hline \multicolumn{1}{|c|}{ Total assets } & \multicolumn{1}{c|}{$\%$} \\
\hline Less than R50 million & 9.20 \\
Between R50 million and R100 million & 10.80 \\
Between R100 million and R500 million & 35.40 \\
Between R500 million and R1 billion & 12.30 \\
More than R1 billion & 32.30 \\
\hline
\end{tabular}

\section{Table 2 Annual sales and size of annual capital budget}

\begin{tabular}{|l|c|c|}
\hline \multicolumn{1}{|c|}{ Item } & $\begin{array}{c}\text { Annual } \\
\text { sales }\end{array}$ & $\begin{array}{c}\text { Annual } \\
\text { capital budget }\end{array}$ \\
\hline Less than R2 million & 0.00 & 10.80 \\
Between R2 million and R5 million & 1.50 & 12.30 \\
Between R5 million and R10 million & 0.00 & 12.30 \\
Between R10 million and R25 million & 0.00 & 12.30 \\
Between R25 million and R50 million & 4.60 & 10.80 \\
Between R50 million and R100 million & 10.80 & 16.90 \\
More than R100 million & 83.10 & 24.60 \\
\hline
\end{tabular}

Annual sales are more than RI00 million for $83.1 \%$ of the respondents while $41.5 \%$ of the respondents' annual capital budgets are more than R50 million (24.6\% more than R100 million and $16.9 \%$ between R50 million and R100 
million). The importance of the capital investment decision can thus be clearly seen when one analyses the amount spent on capital investment projects. For instance, if $24.6 \%$ of the 65 respondents as indicated spend more than R100 million on their annual capital budget, this will amount to more than R1.6 billion in capital investments per annum.

\section{Stages in the capital budgeting process}

As Table 3 illustrates, the majority of respondents regard project definition and cash flow estimation not only as the most important stage in the capital budgeting process but also as the most difficult. Financial analysis and project selection are regarded as the second most important and difficult stage. This implies that these decision makers have a thorough understanding regarding the care that should be taken when capital investment decisions are evaluated, because the successful outcome of a decision depends on the accurate estimation of cash flows and efficient financial analysis of the proposed alternative.

Although the respondents generally regard the project implementation stage as more important than the project review stage, more companies deem the project review stage more difficult.

Table 3 Most important and most difficult stages in the capital budgeting process

\begin{tabular}{|l|c|c|}
\hline \multicolumn{1}{|c|}{ Item } & $\begin{array}{c}\text { Most } \\
\text { important }\end{array}$ & $\begin{array}{c}\text { Most } \\
\text { difficult }\end{array}$ \\
\hline Project definition and cash flow estimation & 66.2 & 46.2 \\
Financial anclysis ard project selection & 26.2 & 29.2 \\
Project implementation & 4.6 & 9.2 \\
Project review & 3.1 & 15.4 \\
\hline & 100 & 100 \\
\hline
\end{tabular}

\section{Cash flow forecast method used}

A list was provided to the respondents with several options, requesting them to indicate which cash flow forecasting methods they use. Table 4 presents these findings. 
Table 4 Cash flow forecasting methods used

\begin{tabular}{|l|c|c|}
\hline \multicolumn{1}{|c|}{ Cash flow forecasting method } & Percentage & Ranking \\
\hline Management Subjective Estimates (MSE) & 20.00 & 3 \\
Consensus of Expert Opinion (CEO) & 1.50 & 7 \\
Quantitative Methods (QM) & 3.10 & 6 \\
MSE \& CEO & 12.30 & 4 \\
MSE \& QM & 23.10 & 2 \\
CEO \& QM & 0.00 & 8 \\
MSE \& CEO \& QM & 35.40 & 1 \\
Cannot say & 4.60 & 5 \\
\hline
\end{tabular}

The majority of respondents utilise a combination of methods to estimate their cash flows. The most popular combination seems to be Management Subjective Estimates in conjunction with Consensus of Expert Opinion and Quantitative Methods (35.4\%). The combination with the second highest popularity seems to be Management Subjective Estimates in conjunction with Quantitative Methods $(23.1 \%)$. It is clear that the use of different combinations of cash flow forecasting methods in estimating future cash flows are used quite extensively, as these combinations amount to a total of $70.8 \%$. An interesting finding, however, is the fact that $20 \%$ of the respondents use only Management Subjective Estimates. If this percentage is added to the $4.6 \%$ of respondents who indicated that they are not able to say, we find that no less than $24.6 \%$ of the respondents do not use a formal cash flow forecasting method to estimate future cash flows.

\section{Techniques used in the capital budgeting process}

When the respondents were asked to indicate which technique they considered to be the most important capital budgeting method, $33.8 \%$ indicated that ROI and $32.3 \%$ indicated that the IRR should be regarded as the most important capital budgeting method. The remaining respondents regarded NPV and PVP as the most important with a percentage distribution of $16.9 \%$ for each of these two techniques. Table 5 illustrates these preferences regarding the capital budgeting method to be used. 
Table 5 Preferences regarding the most important capital budgeting method to be used

\begin{tabular}{|l|c|c|}
\hline \multicolumn{1}{|c|}{ Item } & Importance & Ranking \\
\hline Retum on Investment (ROI) & 33.8 & 1 \\
Internal Rate of Return (IRR) & 32.3 & 2 \\
Net Present Value (NPV) & 16.9 & 3 \\
Present Value Payback (PVP) & 16.9 & 3 \\
Profitability Index (PI) & 0 & N/A \\
Accounting Payback (AP) & 0 & N/A \\
\hline & 100 & \\
\hline
\end{tabular}

In South Africa another study, Parry and Firer (1990: 55) also found that the IRR was the most popular $(43 \%)$, followed by the ROI $(32 \%)$. NPV was reported as being a primary technique by only $10 \%$ of their respondents. A UK study by Pike (Lumby, 1991: 491) showed similar results, with the IRR being consistently more popular than the NPV. Pike's study also asked firms for their reasons for choosing the methods they use. The IRR was thought to be a good device for ranking projects, it was easy to understand as it gave a percentage rate of retum and the technique did not require a discount rate to operate. The NPV came in for considerable adverse comment, such as that it was difficult to understand, unnecessary for short-lived projects, difficult to use because of changing hurdle rates and a questionable technique to use in periods of high inflation (Lumby, 1991: 492).

A USA study by Scapens, Sale \& Tikkas (Lumby, 1991: 492) found that Discounted Cash Flow (DCF) techniques generally were more widespread used in the USA than in the UK. They found that in their sample $84 \%$ of USA companies used DCF techniques, as against only $54 \%$ in the UK.

If the preferences for capital budgeting methods used are analysed according to the size of the annual capital budget as illustrated by Table 6 , it is clear that companies with an annual capital budget in excess of R100 million regard the IRR as the most important capital budgeting method (68.7\%). ROI is regarded as the second most important method $(25 \%)$. 
Table 6 Most important capital budgeting method in terms of annual capital budget

\begin{tabular}{|c|c|c|c|c|c|c|c|}
\hline Technique & $\begin{array}{c}\text { More than } \\
\text { R100m } \\
(n=16)\end{array}$ & $\begin{array}{c}\mathrm{R} 50 \mathrm{~m} \\
\text { to } \\
\mathrm{R} 100 \mathrm{~m} \\
\\
(\mathrm{n}=11)\end{array}$ & $\begin{array}{c}\text { R25m } \\
10 \\
\text { R50m } \\
(n=7) \\
\end{array}$ & $\begin{array}{c}\mathrm{R} 10 \mathrm{~m} \\
\text { to } \\
\mathrm{R} 25 \mathrm{~m} \\
(\mathrm{n}=8)\end{array}$ & $\begin{array}{c}\mathrm{R} 5 \mathrm{~m} \\
\text { to } \\
\mathrm{R} 10 \mathrm{~m} \\
\\
(\mathrm{n}=8)\end{array}$ & $\begin{array}{c}\mathrm{R} 2 \mathrm{~m} \\
10 \\
\mathrm{R} 5 \mathrm{~m} \\
\\
(\mathrm{n}=8)\end{array}$ & $\begin{array}{l}\text { Less } \\
\text { than } \\
\text { R2m } \\
\\
(\mathrm{n}=7)\end{array}$ \\
\hline $\begin{array}{l}\text { Return on Investment } \\
\text { (ROI) }\end{array}$ & 25.0 & 18.2 & 14.3 & 37.5 & 25.0 & 75.0 & 57.2 \\
\hline $\begin{array}{l}\text { Internal Rate of Return } \\
\text { (IRR) }\end{array}$ & 68.7 & 45.5 & 14.3 & 25.0 & 12.5 & 0.0 & 14.3 \\
\hline $\begin{array}{l}\text { Net Present Value } \\
\text { (NPV) }\end{array}$ & 6.3 & 9.1 & 42.9 & 25.0 & 25.0 & 25.0 & 0.0 \\
\hline $\begin{array}{l}\text { Present Value Payback } \\
\text { (PVP) }\end{array}$ & 0.0 & 27.2 & 28.5 & 12.5 & 37.5 & 0.0 & 28.5 \\
\hline Profitability Index (PI) & 0.0 & 0.0 & 0.0 & 0.0 & 0.0 & 0.0 & 0.0 \\
\hline \multirow[t]{2}{*}{$\begin{array}{l}\text { Accounting Payback } \\
\text { (AP) }\end{array}$} & 0.0 & 0.0 & 0.0 & 0.0 & 0.0 & 0.0 & 0.0 \\
\hline & 100 & 100 & 100 & 100 & 100 & 100 & 100 \\
\hline
\end{tabular}

Companies with an annual capital budget between R50 million and R100 million regard Internal Rate of Return as the most important $(45.5 \%)$ and Present Value Payback as the second most important method (27.2\%). Companies with an annual capital budget between R25 million and R50 million and between R10 million and R25 million regard Net Present Value (42.9\%) and Return on Investment $(37.5 \%)$ as the most important method respectively. They respectively deem the Present Value payback (28.5\%) and Internal Rate of Retum in conjunction with the Net Present Value (both 25\%) as the second most important methods to be used in capital investment decisions.

Where the annual capital budget is between R5 million and R10 million, companies seem to regard the Present Value Payback as the most important method to be used (37.5\%) while the Return on Investment in conjunction with Net Present Value (both with $25 \%$ ) are regarded as the second most important methods to be used. Companies with an annual capital budget between R2 million and R5 million and those less than $\mathrm{R} 2$ million regard Retum on Investment as the most important method to be used with percentages of $75 \%$ and $57.2 \%$ respectively. These companies respectively regard Net Present Value (25\%) and Present Value Payback $(28.5 \%)$ as the second most important methods to be used.

An interesting fact is that not one of the respondents regarded Profitability Index or Accounting Payback as an important method to be used in the capital budgeting process. This may indicate that these methods are of little value in 
capital investment decision-making.

The study by Parry and Firer (1990: 55) also found a difference between the techniques used by high and low capital intensity firms. According to their study $65 \%$ of high capital intensity firms prefer the IRR compared to only $24 \%$ of low capital intensity firms. The most popular method for low capital intensity firms is ROI $(47 \%)$, which is an indication of lower sophistication in capital budgeting techniques by companies with a smaller capital budget. This finding is supported by several studies cited in Lumby (1991: 492), which showed that DCF techniques are more popular for larger projects and that larger companies were more likely to use DCF techniques.

With regard to the capital budgeting techniques used, respondents were asked to indicate which capital budgeting technique they most often use when assessing the viability of capital investment projects in general and more specifically with regard to particular operations. Six different operations were identified, namely expansion in new and existing operations, foreign operations, abandonment, general or administrative projects and social projects. Social projects were defined as projects which do not generate any income for the firm and include RDP-projects, pollution control and rehabilitation and environmental programmes. A summary of the various responses is given in Table 7 .

Table 7 Techniques most often used in assessing different operations

\begin{tabular}{|c|c|c|c|c|c|c|c|c|}
\hline Technique & IRR & NPV & PI & $\overline{P V P}$ & $\overline{\mathbf{A P B}}$ & ROI & $\begin{array}{c}\text { Ques- } \\
\text { tion } \\
\mathbf{N} / \mathbf{A}\end{array}$ & Other \\
\hline $\begin{array}{l}\text { Capital Investment } \\
\text { Projects }\end{array}$ & 27.7 & 21.5 & 4.6 & 15.4 & 3.1 & 27.7 & 0.0 & 0.0 \\
\hline $\begin{array}{l}\text { Expansion in existing } \\
\text { operations }\end{array}$ & 30.8 & 9.2 & 4.6 & 18.5 & 3.1 & 32.3 & 1.5 & 0.0 \\
\hline $\begin{array}{l}\text { Expansion in new } \\
\text { operations }\end{array}$ & 29.2 & 12.3 & 7.7 & 12.3 & 0.0 & 38.5 & 0.0 & 0.0 \\
\hline Foreign Operations & 20.0 & 3.1 & 4.6 & 16.9 & 0.0 & 32.3 & 21.5 & 1.5 \\
\hline Abandonment & 20.0 & 10.8 & 7.7 & 10.8 & 4.6 & 30.7 & 9.2 & 6.2 \\
\hline $\begin{array}{l}\text { General / Administrative } \\
\text { projects }\end{array}$ & 12.3 & 10.8 & 7.7 & 20.0 & 10.8 & 21.5 & 6.2 & 10.8 \\
\hline Social projects & 4.6 & 15.4 & 1.5 & 6.2 & 3.1 & 7.7 & 23.1 & 38.5 \\
\hline
\end{tabular}

As can be seen from Table 7, 21.5\% of respondents are not involved in foreign operations, $9.2 \%$ do not have abandonment activities while $6.2 \%$ do not apply capital investment techniques in general or administrative projects. 
When assessing the viability of capital investment projects in general, the majority of respondents indicated that the most often used capital budgeting techniques are IRR and ROI with a percentage rate of $27.7 \%$ each, followed by NPV $(21.5 \%)$ and PVP (15.4\%). With regard to the various operations where applicable (except social projects), all the respondents stated that the most often used and second most often used capital budgeting techniques are ROI and IRR respectively.

With regard to social projects, $38.5 \%$ of the respondents indicated that they use other techniques to assess the viability of these type of projects. These techniques can be divided into five groups, namely, social responsibility and moral (ethical) issues, derived strategic benefits, not seen as capital, legal requirements, and subjectiveness. Table 8 illustrates the distribution amongst the groups of all respondents who indicated that they use another technique to assess the viability of social projects.

Table 8 Distribution per group using other techniques to assess social projects

\begin{tabular}{|l|c|c|}
\hline \multicolumn{1}{|c|}{ Item } & Percentage & Ranking \\
\hline Derived benefits & 30.43 & 1 \\
Social responsibility and moral issues & 26.09 & 2 \\
Subjectiveness & 21.74 & 3 \\
Not seen as capital & 13.04 & 4 \\
Legal requirements & 8.70 & 5 \\
\hline
\end{tabular}

As can be seer. from thc Table 8 , social projects are, to a great extent, evaluated on a subjective basis where management weighs the possible benefits that can be derived against the amount invested in the specific project. These benefits may take the form of goodwill achieved within a community and the perceived fulfillment of a company's social responsibility.

Although the above table ranks legal requirements quite low, it should be noted that legal requirements play an important role in the evaluation of social projects. For instance, not only must companies comply with environmental legislation in terms of pollution control, rehabilitation programmes and conservation standards, these companies are forced to comply with legislation that involves more general spheres of life such as the Equity Bill as well as the Constitution. 
Table 9 Non-financial criteria used in major investment decisions

\begin{tabular}{|l|c|c|}
\hline \multicolumn{1}{|c|}{ Item } & Percentage & Ranking \\
\hline $\begin{array}{l}\text { Investments never accepted on non-financial } \\
\text { grounds }\end{array}$ & 33.80 & 1 \\
Safety of employees or the public & 21.50 & 3 \\
$\begin{array}{l}\text { Necessity of maintaining existing programmes } \\
\text { or product lines }\end{array}$ & 20.00 & 4 \\
Other & 24.70 & 2 \\
\hline & 100 & \\
\hline
\end{tabular}

Table 9 gives a summary of non-financial (qualitative) criteria that respondents use in major investment decisions. It is clear that $33.8 \%$ of all respondents indicated that investments are never accepted on non-financial grounds, whilst $21.5 \%$ of respondents indicated that the safety of their employees or the public influences their capital investment decision. Some $20 \%$ responded that maintaining existing programmes or product lines influences their capital investment decision.

Other international studies also support the finding that qualitative or nonfinancial criteria play a large role. Fremgen (Lumby, 1991: 491) found in a USA survey that $97 \%$ of his respondent companies admitted to having approved investment projects for which the quantitative appraisal techniques had advised rejection. Carsberg and Hope (Lumby, 1991: 491) found that one third of their respondents ranked 'judgment' as the most important appraisal method. One of the reasons proposed by the authors for this was that the use of managerial judgment fitted in with the concept of managerial 'nlair' and entreprereurship.

The stage in the capital budgeting process that the respondents consider to carry the highest risk is illustrated in Table 10 . It was found that $46.2 \%$ regarded project definition and cash flow estimation as the most risky. This correlates with the stage respondents regarded as the most important as well as the most difficult. However, comparing the second most risky stage with the second most important and most difficult (Table 3), we see that the respondents regard project implementation as the second most risky stage in contrast with financial analysis and project selection as second most important and most difficult. 
Table 10 Highest risk stage in capital budgeting process

\begin{tabular}{|l|c|}
\hline \multicolumn{1}{|c|}{ Item } & Highest risk \\
\hline Project definition and cash flow estimation & 46.20 \\
Financial analysis and project selection & 24.60 \\
Project implementation & 29.20 \\
Project review & 0.00 \\
\hline & 100 \\
\hline
\end{tabular}

This trend signifies a possible absence regarding the evaluation of risk in itself, as the focus is placed on the ability to manage the project implementation stage. It seems that as long as the project has been defined and the accompanying cash flows have been estimated, the tendency is to do a financial analysis, select a project and then to implement with a risk focus at the latter stage.

Table 11 gives an indication of the preferences according to the size of the annual capital budget. Companies with an annual capital budget exceeding R50 million regard project definition and cash flow estimation as the most risky stage in the capital budgeting process.

Table 11: Most risky stage according to annual capital budget

\begin{tabular}{|c|c|c|c|c|c|c|c|}
\hline Stage & $\begin{array}{l}\text { More } \\
\text { than } \\
\text { R100m } \\
(n=16)\end{array}$ & $\begin{array}{c}\mathrm{R} 50 \mathrm{~m} \\
\text { to } \\
\text { R100m } \\
\\
(n=11)\end{array}$ & $\begin{array}{c}\mathbf{R 2 5 m} \\
\text { to } \\
\text { R50m } \\
(n=7)\end{array}$ & $\begin{array}{c}\mathrm{R} 10 \mathrm{~m} \\
\text { to } \\
\text { R25m } \\
(\mathrm{n}=8)\end{array}$ & $\begin{array}{c}\text { R5m } \\
\text { To } \\
\text { R10m } \\
\\
(n=8)\end{array}$ & $\begin{array}{c}\mathrm{R} 2 \mathrm{~m} \\
\text { to } \\
\text { R5m } \\
(\mathrm{n}=8)\end{array}$ & $\begin{array}{l}\text { Less } \\
\text { than } \\
\text { R2m } \\
(n=7) \\
\end{array}$ \\
\hline $\begin{array}{l}\text { Project definition and } \\
\text { cash flow estimation }\end{array}$ & 62.5 & 45.5 & 14.4 & 50.0 & 62.5 & 37.5 & 28.6 \\
\hline $\begin{array}{l}\text { Financial analysis and } \\
\text { project selection }\end{array}$ & 6.3 & 18.2 & 42.8 & $12: 5$ & 12.5 & 62.5 & 42.8 \\
\hline Project implementation & 31.2 & 36.3 & 42.8 & 37.5 & 25.0 & 0.0 & 28.6 \\
\hline \multirow[t]{2}{*}{ Project review } & 0.0 & 0.0 & 0.0 & 0.0 & 0.0 & 0.0 & 0.0 \\
\hline & 100 & 100 & 100 & 100 & 100 & 100 & 100 \\
\hline
\end{tabular}

Project implementation is regarded as the stage that carries the second highest risk. Respondents with an annual capital budget between R25 million and R50 million seem to regard the risk element associated with financial analysis and project selection as being the same as that of project implementation. Incidentally, these respondents do not regard project definition and cash flow 
estimation as the stages that carry the highest risk. Respondents with an annual capital budget between R5 million and R25 million have the same preferences as those with an annual capital budget exceeding R50 million in what they regard as the most risky and second most risky stages in the capital budgeting process. Companies with an annual capital budget less than R5 million state that financial analysis and project selection is the stage that carries the highest risk.

\section{CONCLUSION}

Testing the hypotheses, the following results were obtained:

Hypothesis 1 tested negative as the most important stages in the capital budgeting process appear to be project definition and cash flow estimation and not financial analysis.

Hypothesis 2 is difficult to assess as most cash flow forecasting depends on a combination of methods among which quantitative methods appear to be of least value.

Hypothesis 3 tested positive as ROI and IRR are the most generally applied capital investment techniques used by decision-makers. This finding contrasts with the generally accepted view that NPV is superior to other capital budgeting techniques.

Hypothesis 4 tested negative, as companies with smaller capital budgets prefer PVP, medium spenders NPV, and companies with relatively large capital budgets rely consistently on IRR to evaluate capital investment projects.

Hypothesis 5 also tested negative as $64 \%$ of respondents have at some time used non-financial criteria when assessing projects.

An important finding of this research is that in the evaluation of capital investment projects, the preference of South African companies seems to be ROI and IRR as methods to be used in determining the feasibility of a project. The use of these methods is influenced by the size of a company's annual capital budget as there is a correlation between the annual capital budget and a preference for ROI and IRR. As the annual capital budget increases, the tendency is to use these methods more extensively.

The subject of future research on this topic will deal with the question of how well risk is incorporated into the capital investment decision. 


\section{ENDNOTE}

Acknowledgement is hereby given to Mr PG Vosloo and Prof LM Brümmer for their inputs into this article.

\section{REFERENCES}

1 BIERMAN, H. and SMIDT, S. (1993) The Capital Budgeting Decision, $8^{\text {th }}$ ed. New York: Macmillan.

2 DU TOIT, G. S.; NEULAND, E.W. and OOST, E. J. (1997) Capital Investment Decisions, Pretoria: UNISA Press.

3 LUMBY, L. (1991) Investment Appraisal and Financing Decisions, $4^{\text {th }}$ ed. London: Chapman \& Hall.

4 PARRY, H.M.A. and FIRER, C. (1990) Capital Budgeting Under Uncertainty: An Empirical Study, South African Journal of Business Management, 21(3): 52-8.

5 SOUTH AFRICAN RESERVE BANK (1999) Quarterly Bulletin, March (QB). 